

Journal of Aviation Technology and Engineering 5:2 (2016) 69-80

\title{
An Exploratory Study: Correlations Between Occupational Stressors, Coping Mechanisms, and Job Performance Among Chinese Aviation Maintenance Technicians
}

\author{
Yu Wang, Julius C. Keller, Chenyu Huang and Richard O. Fanjoy \\ (Purdue University)
}

\begin{abstract}
Aviation maintenance technicians play a vital role in air transportation. These workers are responsible for keeping aircraft airworthy and executing safety responsibilities. Undesirable stress levels may have a negative impact on work performance (Mowday, Porter, \& Steers, 2013). Poor work performance may manifest in safety violations, absenteeism, turnover, and disengagement. These outcomes may disrupt an organization's operation and negatively impact the financial bottom line. This mixed-methods exploratory research study was aimed at examining the relationships between occupational stress, coping mechanisms, and job performance. Research questionnaires were electronically distributed to frontline aviation maintenance technicians at multiple airlines in China. Eighty-two $(n=82)$ completed surveys were used for data analysis. Results indicated a statistically significant negative correlation between occupational stress and job performance. A positive correlation between occupational stress and coping skills was found, but no significant correlation between job performance and coping mechanisms. Additionally, two open-ended questions were analyzed pertaining to occupational stressors and coping mechanisms. Salary, strenuous work schedule, and limited opportunities for promotion were the top three work-related stressors identified by participants. Taking a break, talking to someone, and exercising were the top three coping mechanisms identified by participants. Along with the results, recommendations for future research to identify causal relationships are discussed.
\end{abstract}

\section{Introduction}

Led by China, the Asia-Pacific market was the second fastest growing aviation market (8.5\%), behind the Middle East, in 2014. Growth in this region has been consistent for longer than a decade (IATA, 2016). As the aviation market grows in China, maintenance personnel may face increasing occupational stress. The job description of aviation maintenance personnel makes this position unique. Factors such as time pressure, safety concerns, irregular shifts, fatigue, and environmental aspects may influence performance (Sun \& Chiou, 2011). According to Tangri (2003), 60 percent of workrelated accidents are attributed to occupational stress. Undesirable psychological characteristics such as high levels of stress may influence the bottom line for an organization. In the United States, occupational stress costs businesses directly and indirectly more than $\$ 300$ billion each year. Without proper mitigation measures such as training programs, a large American organization can expect to lose approximately \$3.6 million annually due to absenteeism alone (UMass 
Lowell, 2016). Though data specific to Chinese aviation maintenance personnel was not found, job stress affects approximately $20 \%$ of Chinese workers (Zhang, Wang, \& $\mathrm{Li}, 2010)$. This data suggests an opportunity to investigate occupational stress, coping mechanisms, and job performance among Chinese aviation personnel.

Most organizations strive to optimize human performance as well as improve policies and training. However, very little research has been done to understand these relationships, especially for Chinese aviation maintenance professionals (Sun \& Chiou, 2011). To better understand the characteristics of aviation professionals and the correlations among occupational stresses, coping mechanisms, and work engagement may enhance the work performance of aviation crews. Therefore, the purpose of this exploratory research study was to examine occupational stress, coping mechanisms, work performance among Chinese aviation maintenance professionals, provide recommendations to the aviation maintenance community, and suggest future research.

\section{Literature Review}

\section{Overview of Stress}

The definition given by Salas, Driskell, and Hughes (1996) is most commonly used to study the effect of stress on human performance. The authors define stress as, "a process by which certain environmental demands evoke an appraisal process in which perceived demand exceeds resources and results in undesirable physiological, psychological, behavioral or social outcomes" (p. 6).

The effect of individual stressors is largely determined by how serious and stressful people perceive them, and not all stressors are bad. A moderate level of stress may counteract boredom and carelessness, thus increasing people's performance (Hancock, 1989). According to the Yerkes-Dodson Law, an individual's performance increases as his or her psychological arousal increases, to a point. However, when the level of arousal is too high, performance decreases (Mark \& Smith, 2012). This can be considered an inverted-U relationship. Stress level is dynamic and inconsistent for different individuals. Simply put, stress levels may change from moment to moment (Thoits, 1995).

For the purpose of this project, the researchers explored three dimensions of occupational stress. According to Cooper and Marshall (1976), stress can derive from dimensions including: intrinsic to the job, relationships at work, and compensation. "Intrinsic to the job" pertains to the physical attributes of the working environment, for example, temperature, lighting, noise, and workspace. It also includes social conditions and mental health. The dimension "relationships at work" pertains to how well an individual is accepted and integrated into the organization. Peers and managers have an influence on workers' daily routines.
"Compensation" refers to the equity of tasks performed and financial compensation. It also includes aspects such as vacation time, break time, and benefits (Cooper \& Marshall, 1976).

\section{Overview of Coping Skills}

In psychology studies, coping refers to expanding conscious effort to deal with interpersonal or personal issues, and trying to mitigate or tolerate stress. The effectiveness of coping strategies depends on the stress category, individual personality, and the circumstances (Sarafino, 2005). Additionally, personality and situational variables, such as life events and working environment, may also affect how individuals implement coping mechanisms. The selection of coping strategies is the result of interaction among individual and external variables (Endler \& Parker, 1994).

Three dimensions of coping mechanisms were examined in the current research study. According to Endler (1982), task oriented, emotionally oriented, and avoidance oriented behaviors are ways through which people tend to cope with stress. People who employ "task oriented" behaviors go directly to the source of stress. For example, if there is a problem that causes stress, an individual will address it in a timely fashion. There is an attempt to control and change the situation in a positive way. This is also considered an example of locus of control by many psychology scholars.

"Emotionally oriented" coping strategies, on the contrary, are more effective when the situation cannot be modified and usually involves subjective stress relief behaviors like prayer, venting, or seeking support from friends or family members (Carver, Scheier, \& Weintraub, 1989). "Avoidance oriented" coping strategies can be used to escape from the stressors mentally through daydreaming, taking a break, or even the use of alcohol and or drugs (Folkman \& Moskowitz, 2004).

\section{Overview of Work Performance}

In the last decade, work performance has become a popular idea for researchers and practitioners. However, throughout the course of investigating the construct, many definitions have emerged (Macey \& Schneider, 2008). For the purpose of this paper, two work performance constructs were discussed and evaluated. The first is task performance. "Task performance" actions can be considered directly related to the organization's technical core. In other words, task performance is the willingness of an employee to complete his or her job duties (Motowidlo \& Van Scotter, 1994). An example of task performance for aviation maintenance professionals might be to follow specific procedures to accurately replace an engine component in a safe and timely fashion. Additionally, aviation maintenance professionals may be required to maintain official records pertinent to the completed work.

The second work performance construct is contextual performance. "Contextual performance" of employees 
contributes to the organization's work culture. This can be described as the worker's willingness to volunteer and help with duties that are not strictly within his or her job description. People who have higher levels of contextual performance are more willing to cooperate and help accomplish the tasks of the organization, even if the task is inconvenient (Boman \& Motowidlo, 1993).

\section{Occupational Stress-Work Performance \\ Theoretical Understanding}

There are several theories pertaining to occupational stress and job performance. Most of the theories that have been put forward can be categorized by the linear relationship. Muse, Harris, and Feild (2003) reviewed occupational stress and performance research studies conducted from the past two decades. Results of the comprehensive review indicated researchers have been extensively exploring the connection between occupational stress and work performance. However, disagreements amongst scholars exist about the relationship among the variables. Some scholars posit there is a negative linear relationship, while others argue the relationship is positive linear, or an inverted-U.

The overload of occupational stress is unfavorable to performance, therefore creating a negative linear relationship (Pincherle, 1972; Jex, 1998). Too much stress can cause psychological and physiological strains. In the positive linear relationship model, stress may improve worker performance (Hatton, Brown, Caine, \& Emerson, 1995; Kahn \& Long, 1988). Studies have shown performance can be reduced if there is too low of a stress level (Meglino, 1977). Workers may become bored, complacent, and disengaged.

The inverted-U theory of the stress-performance relationship combines the negative and positive linear theories. This suggests increasing stress is good for performance up to a point; beyond that point, stress has undesirable effects. Theorists seem to prefer the contingency nature of the inverted-U theory; however, empirical results of stress performance are in favor of the negative linear relationship (Friend, 1982; Jamal, 1984; Jamal, 1985; Westman \& Eden, 1991; Westman \& Eden, 1996). Furthermore, few studies support the inverted-U theory (Anderson, 1976; Srivastava \& Krishna, 1991). Leung, Liu, and Wong (2006) indicated that the absence of effective stress controlling may lead to a decrease in worker performance or other undesirable characteristics. Previous research predicted that occupational stress should be assumed to have a negative impact on the work performance.

Previous literature pertaining to stress and performance indicated stress has a negative impact on team performance (Cannon-Bowers \& Salas, 1998). Research conducted by the National Transportation Safety Board (NTSB) (1994) indicated that the probable cause for several accidents has been a breakdown in crew resource management. Team members under acute stress have lower levels of communicating and a decreasing regard for interpersonal skills, and more often confuse job duties. According to Driskell and Salas (1996), team members under stress often have a diminished ability to make sound decisions. Ellis (2006) investigated the effects of stress on cognitive and behavioral aspects of performance. During the study, participants were placed under stress induced through time pressure. Results showed cognitive and behavioral functions decreased due to the induced stress. To complicate matters regarding research pertaining to stress and performance, it is not always simple to identify stress levels in self-reporting studies. Sexton, Thomas, and Helmreich (2000) evaluated thousands of pilots, nurses, doctors, fellow, and medical residents. Findings suggested $33 \%$ of intensive care staff acknowledged personal errors were made. Fifty percent of intensive care staff reported it was difficult to discuss errors made and job performance. The main reason for this was because of the handling of errors in the workplace by peers and management.

Research regarding management of stress, coping techniques, and job performance has shown positive effects on personnel. Anderson (1977) evaluated 90 participants over a two and half year time period. One focus of the study was to determine if task oriented or emotionally oriented coping mechanisms lead to higher job performance. Results suggested that when participants exhibited the use of task orientated mechanisms versus emotionally oriented mechanisms job performance improved. Sun and Chiou (2011) examined occupational stress, coping mechanism, and work performance among aviation ground crews. Three hundred and forty-two participants responded to surveys. Structural equation modeling was the primary statistical method and provided evidence that occupational stress negatively impacted job performance. Additionally, coping mechanisms influenced job performance. Specifically, task oriented coping had a more positive influence. The results supported previous research that coping mechanisms can mediate occupational stress. The current paper expects the same results.

This section identified, defined, and operationalized the variables of occupational stress, coping mechanisms, and work engagement. Additionally, previous research related to occupational stressors and job performance among aviation personnel was examined. The purpose of this exploratory research was to observe these variables among Chinese aviation maintenance professionals.

\section{Hypotheses}

$\mathrm{H}_{1}$ : There will be a statistically significant negative correlation between the level of occupational stress and coping skills used by Chinese aviation maintenance technicians.

$\mathrm{H}_{2}$ : There will be a statistically significant negative correlation between the level of occupational stress and work performance among Chinese aviation maintenance technicians. 
$\mathrm{H}_{3}$ : There will be a statistically significant positive correlation between coping skills and work performance among Chinese aviation maintenance technicians.

\section{Method}

\section{Research Instrument}

A research questionnaire was developed and electronically distributed. A total of 32 Likert scale items were sectioned into three primary categories: occupational stress, coping mechanisms, and work performance. Each primary category had additional subcategories. The subcategories had four research questionnaire items each. Occupational stress had three subcategories: intrinsic to the job, relationships at work, and compensation. Coping mechanisms had three subcategories: task oriented, emotionally oriented, and avoidance oriented. Work performance included task performance and contextual performance. See Table 1 for categories and subcategories.

The questionnaire items were adapted from validated measures from a study conducted by Sun and Chiou (2011). The study investigated occupational stress, coping mechanisms, and job performance among aviation ground crews that included baggage handlers, ticket agents, and customer service representatives. All of Cronbach's alpha values were greater than 0.7 , indicating high internal consistency (Sun \& Chiou, 2011).

Respondents were given the option to rate items: 1 = Strongly Disagree; 2 = Disagree; 3 = Neutral; $4=$ Agree; $5=$ Strongly Agree. Additionally, the research questionnaire asked participants for demographic information such as: age, gender, work location, and years of experience. Moreover, two open-ended questions were used to further understand participants' top three work-related stressors and coping mechanisms.

The survey was created in English then translated into Mandarin by a native-speaking Mandarin source who was well-versed in English. To improve the face validity of the survey, the researchers presented the survey to four Mandarin-speaking aviation professionals for feedback. Weiner and Craighead (2010) define face validity as "the degree to which test respondents view the content of a test and its items as relevant to the context in which the test is being administered" (p. 637). In other words, face validity is an approach of measuring whether the research instrument seems to measure what it is supposed to measure. In addition, Institutional Review Board approval was obtained before surveys were distributed. Participants were contacted through an online aviation maintenance personnel platform, which included a link to the survey. Then snowball sampling was used to ask participants to contact other potential maintenance technicians to participate in the survey.

\section{Data Analysis}

The data collection period was between February 2015 and March 2015. Both qualitative and quantitative data were collected. The quantitative data was entered into the SPSS statistical package (version 23) and analyzed to determine whether there were significant relationships among the variables. Means of each subcategory were utilized for the correlation analysis. The data was assumed to follow a normal distribution based on the central limit theorem. A priori alpha level of .05 was selected for all statistical testing. However, significant levels were reported if $p<.01$.

With regard to the qualitative data analysis, survey responses were entered into Excel. Two coders read and coded the survey data independently to identify similar themes regarding work stressors encountered by the Chinese maintenance technicians surveyed. Themes were combined based upon an agreement reached by the two coders. The purpose of using multiple coders was to avoid the research bias possibly generated by one survey coder, and to improve the validity of the research study. According to Berg and Lune (2011), "using two or more independent coders ensures that naturally arising categories are used rather than those a particular researcher might hope to locate-regardless of whether the categories really exist" (p. 155).

\section{Results}

\section{Demographic Analysis}

One hundred and twenty-seven participants voluntarily participated in this study. Eighty-two of these participants completed all of the survey questions and only these responses were used for data analysis. All of the participants were frontline maintenance technicians employed at airlines

Table 1.

Categories and subcategories.

\begin{tabular}{lccc}
\hline & & Primary categories & Work performance \\
\cline { 2 - 4 } & Occupational stress & Coping mechanisms & Task performance \\
Sub-categories & Intrinsic to the job & Emotional & Contextual performance \\
& Compensation & Avoidance & \\
& Relationships at work & Task oriented & \\
\hline
\end{tabular}

Note. Each subcategory had four research items totaling 32 Likert scale items. 
Table 2.

Demographic information of survey participants.

\begin{tabular}{lll}
\hline Gender & Male & $72(88 \%)$ \\
& Female & $4(5 \%)$ \\
& Did not report & $6(7 \%)$ \\
Years of Work & $0-5$ & $62(75 \%)$ \\
Experience & $6-10$ & $12(15 \%)$ \\
& $>11$ & $8(10 \%)$ \\
& Did not report & $0(0 \%)$ \\
Age & $18-25$ & $31(38 \%)$ \\
& $26-30$ & $36(44 \%)$ \\
& $>31$ & $8(10 \%)$ \\
Work Location & $7(9 \%)$ \\
& Did not report & $16(20 \%)$ \\
& Beijing & $14(17 \%)$ \\
& Shanghai & $5(6 \%)$ \\
& Shenyang & $5(6 \%)$ \\
& Shijiazhuang & $4(5 \%)$ \\
& Shenzhen & $6(6 \%)$ \\
& Chengdu & $6(6 \%)$ \\
& Urumqi & $20(24 \%)$ \\
& Others & $6(6 \%)$ \\
\hline
\end{tabular}

Note. Percentages are rounded to the nearest whole number.

in China. The names of the airlines were not requested, in order to protect the anonymity of the participants.

Respondents included four females, 72 males, and six participants who chose not to identify their gender. The average age of respondents was 26.64 and the average work experience was 49 months or 4.08 years. Table 2 shows the demographic information of the survey participants.

\section{Reliability Analysis}

A Cronbach's alpha test was conducted to test the internal consistency. Two dimensions, task oriented and avoidance oriented, in the category of coping mechanisms had a Cronbach's alpha level of lower than 0.6. Therefore, they were removed from the data analysis. Table 3 indicates details for the Cronbach's alpha's results.

\section{Quantitative Results}

With regard to $\mathrm{H}_{1}$ : There will be a statistically significant negative correlation between the level of occupational stress and coping skills used by Chinese aviation main-tenance technicians. The data provided enough evidence to reject the null hypothesis and accept the alternative. Results indicated a significant positive correlation between occupational stress and coping mechanisms: intrinsic to the job and emotionally oriented $(r=0.343, p=0.002)$ at a significance level of $\alpha=0.01$; compensation and emotionally oriented $(r=0.221$, $p=0.046$ ) at a significance level of $\alpha=0.05$.

With regard to $\mathrm{H}_{2}$ : There will be a statistically significant negative correlation between the level of occupational
Table 3.

Cronbach's alpha results.

\begin{tabular}{|c|c|c|c|c|c|c|c|c|}
\hline & IJ & RW & $\mathrm{CO}$ & TO & EO & AO & JP & $\mathbf{C P}$ \\
\hline $\begin{array}{c}\text { Cronbach's } \\
\alpha\end{array}$ & 0.663 & 0.700 & 0.725 & $0.560 *$ & 0.719 & $0.517 *$ & 0.715 & 0.620 \\
\hline$N$ of items & 4 & 4 & 4 & 4 & 4 & 4 & 4 & 4 \\
\hline
\end{tabular}

stress and work performance among Chinese aviation maintenance technicians. The data showed evidence to reject the null hypothesis and accept the alternative. Results indicated a significant negative correlation between occupational stress and work performance: intrinsic to the job and contextual performance $(r=-0.410, p=0.000)$ at a significance level of $\alpha=0.01$, and compensation and contextual performance $(r=-0.384, p=0.000)$ at a significance level of $\alpha=.01$.

With regard to $\mathrm{H}_{3}$ : There will be a statistically significant positive correlation between coping skills and work performance among Chinese aviation maintenance technicians. The data analysis did not find significant correlations between coping skills and work performance. Testing outcomes resulted in a failure to reject the null hypothesis. Table 4 illustrates details for the correlations.

\section{Qualitative Results}

Two open-ended questions were included in the survey. The researchers coded the survey responses separately and then reached a collective consensus. The first open-ended question was "Please write the three most stressful aspects at your job. For example, salary, schedule, time pressure, multitasking, coworkers." Eighty-one participants completed this survey question. Fifty-two (64\%) respondents indicated low compensation as a main stressor. The respondents thought that normally salary was not commensurate with the work completed. One respondent stated: "To my job, there is a serious imbalance between the rewards and the efforts. The money I make is not worth my effort" (translated). Those who live in big cities are more worried about their income, as they have to afford higher living costs.

The second highest work stressor identified by respondents was strenuous work schedule. Fifty (62\%) respondents indicated that their work schedule was not conducive to positive work-life balance. Typically, Chinese airlines utilize 24-hour or 12-hour work shifts. That means frontline technicians have to work overnight. Previous research has indicated night shift work may cause sleep disorders and pose health risks (Shields, 2002). Several respondents also indicated that they had very limited time off work or rest time due to working overtime. Even when they are not on 
Table 4.

Correlations between occupational stress, coping mechanisms and work engagement.

\begin{tabular}{|c|c|c|c|c|c|c|c|}
\hline & & IJ & RW & $\mathrm{CO}$ & EO & $\mathbf{J P}$ & $\mathbf{C P}$ \\
\hline \multirow{3}{*}{$\mathrm{IJ}$} & Correlation & 1 & $0.484^{* *}$ & $0.560^{* *}$ & $0.343^{* *}$ & 0.052 & $-0.410^{* *}$ \\
\hline & Sig. & & 0.000 & 0.000 & 0.002 & 0.643 & 0.000 \\
\hline & $\mathrm{N}$ & 82 & 82 & 82 & 82 & 82 & 82 \\
\hline \multirow{3}{*}{ RW } & Correlation & $0.484^{* *}$ & 1 & $0.543^{* *}$ & 0.193 & -0.004 & $-0.474^{* *}$ \\
\hline & Sig. & 0.000 & & 0.000 & 0.082 & 0.974 & 0.000 \\
\hline & $\mathrm{N}$ & 82 & 82 & 82 & 82 & 82 & 82 \\
\hline \multirow{3}{*}{$\mathrm{CO}$} & Correlation & $0.560^{* *}$ & $0.543^{* *}$ & 1 & $0.221^{*}$ & 0.031 & $-0.384^{* *}$ \\
\hline & Sig. & 0.000 & 0.000 & & 0.046 & 0.782 & 0.000 \\
\hline & $\mathrm{N}$ & 82 & 82 & 82 & 82 & 82 & 82 \\
\hline \multirow{3}{*}{$\mathrm{EO}$} & Correlation & $0.343^{* *}$ & 0.193 & $0.221^{*}$ & 1 & 0.012 & -0.031 \\
\hline & Sig. & 0.002 & 0.082 & 0.046 & & 0.917 & 0.785 \\
\hline & $\mathrm{N}$ & 82 & 82 & 82 & 82 & 82 & 82 \\
\hline \multirow{3}{*}{$\mathrm{JP}$} & Correlation & 0.052 & -0.004 & 0.031 & 0.012 & 1 & $0.427^{* *}$ \\
\hline & Sig. & 0.643 & 0.974 & 0.782 & 0.917 & & 0.000 \\
\hline & $\mathrm{N}$ & 82 & 82 & 82 & 82 & 82 & 82 \\
\hline \multirow{3}{*}{$\mathrm{CP}$} & Correlation & $-0.410^{* *}$ & $-0.474^{* *}$ & $-0.384^{* *}$ & -0.031 & $0.427^{* *}$ & 1 \\
\hline & Sig. & 0.000 & 0.000 & 0.000 & 0.785 & 0.000 & \\
\hline & $\mathrm{N}$ & 82 & 82 & 82 & 82 & 82 & 82 \\
\hline
\end{tabular}

Note. $* *=$ Correlation is significant at the 0.01 level. $*=$ Correlation is significant at the 0.05 level. IJ $=$ intrinsic to the job, RW $=$ relationships at work, $\mathrm{CO}=$ compensation, $\mathrm{TO}=$ task oriented, $\mathrm{EO}=$ emotionally oriented, $\mathrm{AO}=$ avoidance oriented, $\mathrm{JP}=$ job performance, and $\mathrm{CP}=$ contextual performance.

duty, they have to attend regular meetings and training that occupy their time off.

Twenty-two $(27 \%)$ survey participants were not satisfied about the number three work stressor: limited promotion opportunities. For example, one respondent stated that "We have limited career growth and it is extremely hard to get promoted" (translated). Additional concerns expressed by survey respondents were multiple job tasks, safety issues, and relationships with company leaders. See Table 5 for respondents' top three work-related stressors.

Sixty-five participants responded to the second openended question: "Please list your top three coping mechanisms you use when encountering work-related stress." The most common coping mechanism, used by 29 (45\%) participants, was to take a break when they felt stress at work. Talking to others was the second most commonly used coping mechanism when dealing with work stress. Twenty (31\%) participants chose to talk to their friends, family members, or others to release their work stress. Exercising was the third most commonly used coping mechanism to reduce work stress, chosen by 15 (24\%) frontline maintenance technicians surveyed. Playing sports and working out were common activities identified by respondents who chose to exercise. Other techniques used to manage work stress by the participants were to complete easy tasks and get enough rest. Table 6 shows respondents' top three work-related coping mechanisms.

\section{Discussion}

The purpose of this exploratory research was to understand the relationships between work stress, coping mechanisms, and work performance among Chinese frontline aviation maintenance technicians. The results indicated a significant negative correlation between work stress and job performance. This means low work stress is correlated with high work performance, and high work stress is correlated with low work performance. This result is consistent with the results of the previous study conducted by Sun and Chiou (2011). Even though a significant correlation cannot be considered a causal relationship, this can still provide a good understanding of the relationship between work performance and occupational stress. Reducing maintenance technicians' work stress may improve their job performance. This change may assist with reducing turnover, absenteeism, and illnesses while improving workrelated task performance.

In addition, the results indicated a positive correlation between work stress and coping skills and no correlation between work performance and coping skills. These results are not consistent with previous studies. This may be because the employees do not have effective coping skills or techniques to address their work stress. It also may be due to a small and non-representative sample size. Based on the responses to the open-ended survey questions, the survey participants had more to discuss about their occupational stress and less about their coping skills to deal with occupational stress. Eighty-one survey respondents completed the work stress survey question with 2,638 Chinese characters (approximately 33 characters per response). By contrast, 966 Chinese characters were collected from 65 survey respondents (approximately 15 characters per response) for the coping mechanism openended question. It seems that Chinese aviation technicians 
Table 5 .

Respondents top three work-related stressors.

\begin{tabular}{lc}
\hline Top three work-related stressors & Number and percentage of respondents $(\boldsymbol{n}=\mathbf{8 1})$ \\
\hline Compensation & $52(64 \%)$ \\
Strenuous work schedule & $50(62 \%)$ \\
Limited promotion opportunities & $22(27 \%)$ \\
\hline
\end{tabular}

Note. Percentages are approximate values. Respondents had the opportunity to report multiple work stressors.

Table 6.

Respondents top three coping mechanisms.

\begin{tabular}{lc}
\hline Respondents top three work-related coping mechanisms & Number and percentage of respondents $(\boldsymbol{n}=\mathbf{6 5})$ \\
\hline Take a break & $29(45 \%)$ \\
Talking to others & $20(31 \%)$ \\
Exercise & $15(24 \%)$ \\
\hline
\end{tabular}

Note. Percentages are approximate values. Respondents had the opportunity to report multiple coping mechanisms.

experienced much pressure from their jobs, especially with respect to compensation, work schedule, and promotion opportunities. However, the three most commonly used coping mechanisms (taking a break, talking to others, and exercising) could not release their work stress effectively. As one respondent stated, "As aviation mechanics, we even do not have time to think about the work pressure. The only thing we can do is to face the stress calmly" (translated).

Employees who perceive high work stress and demonstrate low coping skills tend to have low contextual and task work performance (Sun \& Chiou, 2011). Aviation maintenance technicians play a vital role in air transportation. Not only do these workers keep aircraft airworthy, but they are also responsible for aviation safety. A low performance in aviation maintenance may cause fatal accidents. Airlines may need to devote more attention to actions that release the work stress that technicians face. Furthermore, it would be helpful for airlines to reevaluate their training programs that address coping skills, thereby improving employees' capability of dealing with work stress.

This exploratory research study had some limitations that must be acknowledged. The small sample size constricted the researchers' ability to draw more reliable conclusions. Issues with internet lag during survey completion were reported by several respondents. Some were unable to open or complete the survey. Due to the small sample size, it would be inappropriate to generalize these results to the entire Chinese frontline maintenance population. In addition, the majority of survey participants were younger than 30 years old with less than five years of work experience. Inexperienced and experienced employees may have different perceptions toward work stress and coping mechanisms. Research including workers at different levels of work experience in aviation is recommended for future studies in this area.
Furthermore, this research only explored correlated relationships among occupational stress, coping mechanisms, and job performance. This cannot confirm a causeand-effect relationship. Future studies identifying causal relationships are recommended.

\section{Conclusion}

This was an exploratory research study with the purpose of examining the relationships between occupational stress, coping skills, and job performance among frontline aviation maintenance technicians in China. The results indicated a negative correlation between work stress and job performance. Additionally, a positive correlation between work stress and coping skills was found; however, the results did not indicate significant correlations between job performance and coping skills. More importantly, this exploratory research may provide aviation professionals with insights useful to personnel and training programs.

\section{References}

Anderson, C. R. (1976). Coping behaviors as intervening mechanisms in the inverted-U stress-performance relationship. Journal of Applied Psychology, 61(1), 30.

Anderson, C. R. (1977). Locus of control, coping behaviors, and performance in a stress setting: A longitudinal study. Journal of Applied Psychology, 62(4), 446.

Berg, B. L., \& Lune, H. (2011). Qualitative research methods for the social sciences. New York: Pearson.

Boman W. G., \& Motowidlo, S. J. (1993). Task performance and contextual performance: The meaning for personnel selection research. Human Performance, 10(2), 99-109.

Cannon-Bowers, J. A., \& Salas, E. E. (1998). Making decisions under stress: Implications for individual and team training. Washington, DC: American Psychological Association.

Carver, C. S., Scheier, M. F., \& Weintraub, J. K. (1989). Assessing coping strategies: A theoretically based approach. Journal of Personality and Social Psychology, 56(2), 267-283. 
Cooper, C. L., \& Marshall, J. (1976). Occupational sources of stress: A review of the literature relating to coronary heart disease and mental ill health. Journal of Occupational and Organizational Psychology, 49(1), 11-28.

Driskell, J. E., and Salas, E. (1996). Stress and human performance. Mahwah, NJ: L. Erlbaum.

Ellis, A. P. (2006). System breakdown: The role of mental models and transactive memory in the relationship between acute stress and team performance. Academy of Management Journal, 49, 576-589.

Endler, N. S. (1982). Interactionism: A personality model, but not yet a theory. In, Nebraska symposium on motivation. Lincoln: University of Nebraska Press.

Endler, N. S., \& Parker, J. D. (1994). Assessment of multidimensional coping: Task, emotion, and avoidance strategies. Psychological assessment, 6(1), 50-60.

Folkman, S., \& Moskowitz, J. T. (2004). Coping: Pitfalls and promise. Annual Review of Psychology, 55, 745-774.

Friend, K. E. (1982). Stress and performance: Effects of subjective workload and time urgency. Personnel Psychology, 35(3), 623-633.

Hancock, P. A. (1989). A dynamic model of stress and sustained attention. Journal of the Human Factors and Ergonomics Society, 31(5), 519537.

Hatton, C., Brown, R., Caine, A., \& Emerson, E. (1995). Stressors, coping strategies and stress-related outcomes among direct care staff in staffed houses for people with learning disabilities. Mental Handicap Research, 8(4), 252-271.

International Aviation Transport Association. (2016). Robust passenger demand continues. Retrieved from https://www.iata.org/pressroom/pr/ Pages/2015-09-04-02.aspx

Jamal, M. (1984). Job stress and job performance controversy: An empirical assessment. Organizational Behavior and Human Performance, 33(1), 1-21.

Jamal, M. (1985). Relationship of job stress to job performance: A study of managers and blue-collar workers. Human Relations, 38(5), 409-424.

Jex, S. M. (1998) Stress and job performance: Theory, research, and implications for managerial practice. London: Sage Publications.

Kahn, S. E., \& Long, B. C. (1988). Work-related stress, self-efficacy, and well-being of female clerical workers. Counselling Psychology Quarterly, 1(2-3), 145-153.

Leung, M. Y., Liu, A. M., \& Wong, M. M. K. (2006). Impact of stresscoping behaviour on estimation performance. Construction Management and Economics, 24(1), 55-67.

Macey, W. \& Schneider, B. (2008). The meaning of employee engagement. Industrial and Organizational Psychology, 1, 3-30.

Mark, G., \& Smith, A. P. (2012). Effects of occupational stress, job characteristics, coping, and attributional style on the mental health and job satisfaction of university employees. Anxiety, Stress \& Coping, 25(1), 63-78.

Meglino, B. M. (1977). Stress and performance: Are they always incompatible? Supervisory Management, 22(3), 22-33.
Mowday, R. T., Porter, L. W., \& Steers, R. M. (2013). Employeeorganization linkages: The psychology of commitment, absenteeism, and turnover. London: Academic Press.

Motowidlo, S. J., \& Van Scotter, J. R. (1994). Evidence that task performance should be distinguished from contextual performance. Journal of Applied Psychology, 79(4), 475-480.

Muse, L. A., Harris, S. G., \& Feild, H. S. (2003). Has the inverted-U theory of stress and job performance had a fair test? Human Performance, 16(4), 349-364.

National Transportation Safety Board. (1994). Safety study: A review of flightcrew-involved major accidents of US air carriers, 1978 through 1990. Washington, DC. Retrieved from http://libraryonline.erau.edu/ online-full-text/ntsb/safety-studies/SS94-01.pdf

Pincherle, G. (1972). Assessment of the relationship between stress and work performance. Proceedings of the Royal Society of Medicine, 65(4), 321-331.

Salas, E., Driskell, J. E., \& Hughes, S. (1996). The study of stress and human performance. Mahwah, NJ: L. Erlbaum.

Sarafino, E. P. (2005). Research methods: Using processes and procedures of science to understand behavior. Upper Saddle RiverNJ: Prentice Hall.

Sexton, J. B., Thomas, E. J., \& Helmreich, R. L. (2000). Error, stress, and teamwork in medicine and aviation: Cross sectional surveys. Bmj, 320(7237), 745-749.

Shields, M. (2002). Shift work and health. Health Reports, 13(4), 11-33.

Srivastava, A. K., \& Krishna, A. (1991). A test of inverted "U"-hypothesis of stress-performance relationship in the industrial context. Psychological Studies, 36(1), 34-38.

Sun, K-S., \& Chiou, H. (2011). Aviation ground crews: Occupational stresses and work performance. African Journal of Business Management, 5(7), 2865-2873.

Tangri, R. (2003). Stress costs, stress cures. Victoria, BC: Trafford Publishing.

Thoits, P. A. (1995). Stress, coping, and social support processes: Where are we? What next? Journal of Health and Social Behavior, 53-79.

UMass Lowell. (2016). Financial costs of job stress. Retrieved from https://www.uml.edu/Research/Centers/CPH-NEW/stress-at-work/ financial-costs.aspx

Weiner, I. B., \& Craighead, W. E. (2010). The Corsini Encyclopedia of Psychology. Hoboken, NJ: Wiley.

Westman, M., \& Eden, D. (1991). Implicit stress theory: The spurious effects of stress on performance ratings. Journal of Social Behavior and Personality, 6(7), 127.

Westman, M., \& Eden, D. (1996). The inverted-U relationship between stress and performance: A field study. Work \& Stress, 10(2), 165-173.

Zhang, X., Wang, Z., \& Li, T. (2010). The current status of occupational health in China. Environmental health and preventive medicine, 15(5), 263-270. 
Appendix A: Chinese Aviation Maintenance Technicians: The Relationship among Occupational Stresses, Coping Mechanisms, and Work Performance

This study aims to understand your perception of occupational stresses, coping mechanisms and job performance. All questions should be answered in regards to your personal experience and practices.

Age/

Gender/

Years of Work Experience/

City Where You Work /

Occupational Stresses

Intrinsic to the $J o b(Q 1-4)$

I often feel upset because of something that happened unexpectedly at work.

Strongly Disagree Disagree Neutral Agree Strongly Agree

$\begin{array}{llllr}1 & 2 & 3 & 4 & 5\end{array}$

I often feel stressed at work.

$\begin{array}{ccccc}\text { Strongly Disagree } & \text { Disagree } & \text { Neutral } & \text { Agree } & \text { Strongly Agree }\end{array}$

I have considered switching to a less stressful career or job.

$\begin{array}{ccccc}\text { Strongly Disagree } & \text { Disagree } & \text { Neutral } & \text { Agree } & \text { Strongly Agree } \\ 1 & 2 & 3 & 4 & 5\end{array}$

The conditions at my job are not sufficient for safe operations. For example, lighting, temperature, protective gear, etc. Strongly Disagree

$\begin{array}{cccc}\text { Disagree } & \text { Neutral } & \text { Agree } & \text { Strongly Agree } \\ 2 & 3 & 4 & 5\end{array}$

1

2

3

4

5

Relationships at work (5-8)

My supervisors do not allow me to provide important input that influences my job.

$\begin{array}{ccccc}\text { Strongly Disagree } & \text { Disagree } & \text { Neutral } & \text { Agree } & \text { Strongly Agree } \\ 1 & 2 & 3 & 4 & 5\end{array}$

I do not have positive working relationships with coworkers.

$\begin{array}{ccccc}\text { Strongly Disagree } & \text { Disagree } & \text { Neutral } & \text { Agree } & \text { Strongly Agree } \\ 1 & 2 & 3 & 4 & 5\end{array}$

I do not feel supported by my superiors at work.

$\begin{array}{ccccc}\text { Strongly Disagree } & \text { Disagree } & \text { Neutral } & \text { Agree } & \text { Strongly Agree } \\ 1 & 2 & 3 & 4 & 5\end{array}$

I do not understand what my superiors expect of me.

$\begin{array}{ccccc}\text { Strongly Disagree } & \text { Disagree } & \text { Neutral } & \text { Agree } & \text { Strongly Agree } \\ 1 & 2 & 3 & 4 & 5\end{array}$

Compensation (9-12)

My pay is not fair compensation for my work.
Strongly Disagree
Disagree
Neutral
Agree
Strongly Agree
1
2
3
4
5 
My hours of work are not desirable.

$\begin{array}{ccccc}\text { Strongly Disagree } & \text { Disagree } & \text { Neutral } & \text { Agree } & \text { Strongly Agree } \\ 1 & 2 & 3 & 4 & 5\end{array}$

My vacation time is not adequate.

$\begin{array}{ccccc}\text { Strongly Disagree } & \text { Disagree } & \text { Neutral } & \text { Agree } & \text { Strongly Agree } \\ 1 & 2 & 3 & 4 & 5\end{array}$

I am not allowed to take short breaks during a typical work day.

$\begin{array}{ccccc}\text { Strongly Disagree } & \text { Disagree } & \text { Neutral } & \text { Agree } & \text { Strongly Agree } \\ 1 & 2 & 3 & 4 & 5\end{array}$

Please write the three most stressful aspects at your job. For example, salary, schedule, time pressure, multitasking, coworkers.

1.

2.

3.

Coping Mechanisms

Task Oriented (13-16)

I stay organized and manage my time effectively at work.

$\begin{array}{ccccc}\text { Strongly Disagree } & \text { Disagree } & \text { Neutral } & \text { Agree } & \text { Strongly Agree } \\ 1 & 2 & 3 & 4 & 5\end{array}$

I ask for help when necessary at work.

$\begin{array}{ccccc}\text { Strongly Disagree } & \text { Disagree } & \text { Neutral } & \text { Agree } & \text { Strongly Agree }\end{array}$

I consider different solutions to complicated problems at work.

$\begin{array}{ccccc}\text { Strongly Disagree } & \text { Disagree } & \text { Neutral } & \text { Agree } & \text { Strongly Agree }\end{array}$

I act immediately to relieve stressful situations at work.

$\begin{array}{ccccc}\text { Strongly Disagree } & \text { Disagree } & \text { Neutral } & \text { Agree } & \text { Strongly Agree } \\ 1 & 2 & 3 & 4 & 5\end{array}$

Emotionally Oriented (17-20)

I worry when stress becomes too much at work.

$\begin{array}{ccccc}\text { Strongly Disagree } & \text { Disagree } & \text { Neutral } & \text { Agree } & \text { Strongly Agree } \\ 1 & 2 & 3 & 4 & 5\end{array}$

I become tense when stress becomes too much at work.

$\begin{array}{ccccc}\text { Strongly Disagree } & \text { Disagree } & \text { Neutral } & \text { Agree } & \text { Strongly Agree } \\ 1 & 2 & 3 & 4 & 5\end{array}$

I blame myself during stressful times at work.

$\begin{array}{ccccc}\text { Strongly Disagree } & \text { Disagree } & \text { Neutral } & \text { Agree } & \text { Strongly Agree } \\ 1 & 2 & 3 & 4 & 5\end{array}$

When stress becomes too much, I tend to take it out on others.

$\begin{array}{ccccc}\text { Strongly Disagree } & \text { Disagree } & \text { Neutral } & \text { Agree } & \text { Strongly Agree }\end{array}$


Avoidance Oriented (21-24)

I take a break when stress on the job becomes too much.

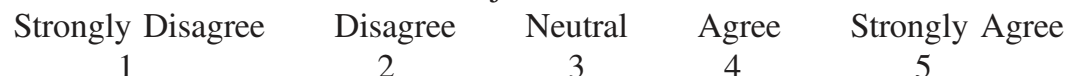

$\begin{array}{lllll}1 & 2 & 3 & 4 & 5\end{array}$

I perform an easier task when stress on the job becomes too much.

$\begin{array}{ccccc}\text { Strongly Disagree } & \text { Disagree } & \text { Neutral } & \text { Agree } & \text { Strongly Agree } \\ 1 & 2 & 3 & 4 & 5\end{array}$

I talk to other coworkers when stress on the job becomes too much.

$\begin{array}{ccccc}\text { Strongly Disagree } & \text { Disagree } & \text { Neutral } & \text { Agree } & \text { Strongly Agree } \\ 1 & 2 & 3 & 4 & 5\end{array}$

It is easy for me to think of other things when stress becomes too much at work.

Strongly Disagree Disagree Neutral Agree Strongly Agree

$\begin{array}{lllll}1 & 2 & 3 & 4 & 5\end{array}$

Please list your top three coping mechanisms you use when encountering workrelated stress.

1 .

2 .

3.

Job Performance

Task Oriented (25-28)

Getting the job done accurately is important.

Strongly Disagree Disagree Neutral Agree Strongly Agree

$\begin{array}{lllll}1 & 2 & 3 & 4 & 5\end{array}$

Getting the job done safely is important.

$\begin{array}{ccccc}\text { Strongly Disagree } & \text { Disagree } & \text { Neutral } & \text { Agree } & \text { Strongly Agree } \\ 1 & 2 & 3 & 4 & 5\end{array}$

Getting the job done efficiently is important.

Strongly Disagree Disagree Neutral Agree Strongly Agree

$\begin{array}{llllll}1 & 2 & 3 & 4 & 5\end{array}$

It is important to think of ways to do my job better.

$\begin{array}{ccccc}\text { Strongly Disagree } & \text { Disagree } & \text { Neutral } & \text { Agree } & \text { Strongly Agree } \\ 1 & 2 & 3 & 4 & 5\end{array}$

Contextual Performance (29-32)

I am willing to work extra when necessary.

$\begin{array}{ccccc}\text { Strongly Disagree } & \text { Disagree } & \text { Neutral } & \text { Agree } & \text { Strongly Agree } \\ 1 & 2 & 3 & 4 & 5\end{array}$

I am willing to do tasks outside of my normal function.

$\begin{array}{ccccc}\text { Strongly Disagree } & \text { Disagree } & \text { Neutral } & \text { Agree } & \text { Strongly Agree } \\ 1 & 2 & 3 & 4 & 5\end{array}$


I am willing to help coworkers when necessary.

Strongly Disagree

1
Disagree 2

\begin{abstract}
Neutral
\end{abstract}
3
Agree
4

\section{Strongly Agree} 5

It is important to follow organizational rules and procedures.

$\begin{array}{ccccc}\text { Strongly Disagree } & \text { Disagree } & \text { Neutral } & \text { Agree } & \text { Strongly Agree } \\ 1 & 2 & 3 & 4 & 5\end{array}$

2

4

5 